\title{
An Untraditional Description Style in the Epos of Ikrom Otamurod
}

\author{
Urakova Nafosat, Dilrabo Quvvatova
}

\begin{abstract}
This article describes the $p$ eculiarity, form and methodological updates of the Uzbek epos during independent years. An example of poet Ikrom Otamurad's epoch such as "Inner-External ...", "Bird", "Table", "Light of the spirit", and modern interpretation and unique description of poetry are analyzed and interpreted.
\end{abstract}

Keywords : Unusual style of description, lyric hero, symbol, poetic syntax, symbolic title, modern tone, geometric element.

\section{INTRODUCTION}

$\mathrm{D}$ uring the years of independence, the Uzbek literature was revamped in poetry, and particularly, in epos. Because the poetry of this period paid much attention to the discovery of the inner world. Particularly, he was moved to express his heart to himself. If we look at the pages of Uzbek epos in recent years, it can be seen that the desire to express content and lyrical heroic feelings through nonviolent poetic forms is exacerbated. Consequently, these features appear in the poems of famous poet I. Otamurod . Every creator's artistic world - his life experience, knowledge level, taste, beauty, imagination and fantasy, the point of view belongs to himself and this connection is reflected in each of his works. The artistic style of the poet's feeling and emotions, which is reflected in the poet's mind, is created. The technique is not only a form of phenomenon, but also direct and indirect. Ikram Otamurod's poems differ from modern Uzbek poems in terms of the image style, lyrical heroic status, richness of factors and symbols, and poetic syntax. It should be noted that these aspects have led to the creation of non-traditional works in contemporary styles. As a result, the artistic creativity has shattered traditional molds and modern tune.

\section{METHODS AND ANALYSIS}

One of the peculiarities of modern Uzbek poems is the feeling of human experiences through the lyric "I". The so-called human body is an entire episode. The modifications of his soul are vast. Looking at the bottom of the heart, you see the diverse landscapes of life. Everything that is present in society, in social life, is the result of neglecting of the negative consequences of all the adventures. Ikrom Otamurod is a kangul poet. His lyrical hero goes a different way to replenish

Revised Manuscript Received on July 22, 2019.

Urakova Nafosat, A teacher at Bukhara State University, Uzbekistan. Email: adabiy86@mail.ru

Dilrabo Quvvatova, A professor of Bukhara State University, Uzbekistan this emptiness, that is, looking at the heart ... He seeks the heart from heart, hoping to find out what he wants, sorrow, harmony, grief, all his soul, !!) and screams like an ocean when it is the time!

Канглумнинг ичига кириб бораман,

ўзимни ахтариб, ўзим.

Зора топсам, зора- а, ман,

жоним тўзиб?!

“Ўзинг керагинг қил!” дейди у,

“Ўзинг ярагинг бил !” дейди у.

“Ў

ич-ичидан шивир-шивирлаб,

ташқарига чиқмай

довуши...

("Internal...external")

Ikrom Otamurod is full of stunning and fascinating feelings of the world and the ends of human beings. He interprets the situation as incompetent and seems to draw his works according to his style:

$$
\text { ... Одам }
$$

Заминга бағрингиз берганмисиз хеч???

... Одам

хеч термилиб боққанмисиз осмонга???

... Одам

уммоннинг ақсосига хеч ўлтирганмисиз???

... Ёндош бўлсангиз,

мабод,

зардоб бойлаган дардингизни,

қайғунгизни,

ғамингизни сўриб олади....

(Table)

One of the peculiarities of the Uzbek poetry of Independence was the fact that the poets used poetic speech such as speech, reference, lyricism, psychological analysis, rhetorical questioning, and the world's knowledge through purification of the human world, poetic ideas of philosophical and poetic ideas of the poets, and they are understood by the considerable ideas and emotions imposed on unique essays. 
Зорларига зорим қўшилар яраб,

қиламан қушга илтижо:

$$
\text { сен - малулсан, мен - да, малул, }
$$

сен менга, мен сенга кангул;

Achieving the revival of symbolic images in the eyes of the poet is the pledge of success in expressing the poetic idea. The literary scholar Noman Rakhimjonov gives a clear conclusion: "The logical representation of thinking through symbolic images has become one of the most important forms of truth in later years of poetry. "(" Uzbek Poetry of Independence "," Principles, Experiments and Lessons ", N. Rakhimjonov, Tashkent," Sciences ", Tashkent, 2007 53p. The same feature is reflected in poems Ikrom Otamurod's poems. In his expression, we come across with unexpected symbols, symbols of (devils, desires, rain, rainbow, mules, horses, dogs, etc.) at every step. It should be noted that the symbols are especially important ("Bird", "Spot" "Table" and "Light of Spirit"). The bird and window symbols in the epos "Bird" parallel to the poet's artistic purpose. If the bird lyric is "I", the window is an image of eternal home where her childhood had passed:

Айланиб,

айланиб келаверар қуш

эски уйда очиқ турган дарчага.

ёвуқми шунга тоблар хуш,

мехр шевалари шунда ёлчиган.

Bird went to the God's address. His motto is to keep silent, to keep silent on his body. Looking for silence through the noise, he slipped into the broken window (?). Unfortunately,

Шовқинлар измидан

шовқинлар ундириб,

шовқинлар

шовқинларга

шавқ-ла талпинар.

Bird - maled (suffered, frustrated, sad). Nevertheless, the bird's spirit shines in the light of the shadows. My dear, he is looking for something in the silence of "the tricks of the tires". In essence, the search for life is for meaning and perception of life.

\section{DISCUSSION}

There are several aspects of artistic and natural sophistication. One of them is the author's works, his paintings, and his close relationship with his life style and biography. Especially in the lyric, such an in-depth connection and genius are invaluable. Such closeness is felt in the poetry of Ikrom Otamurod.

The tendency of new style and interpretation of the essence of personality is reflected in today's poetry, in particular in Uzbek poems, and is characterized by the mood of the heart. There is a struggle between man's inner world, internal conflicts, spirit and body. The essence of all social and spiritual conflicts is that of the human nature and its inner
Олисми,

world. The poet can looks for but find out how easy it is to search for a soul, looks for During his lifetime he is surrounded by trivialities; why is it that there is no place in the minds of people, in the minds of the minds, in the spirit of the world, why a person is not interested in the process of the questions, the thoughts, the agony of questioning his conscience and there is no place for kanglu as well. He wants to teach his reader in the world, most importantly, the kanglu, and all the other events in the transient epos.

The poet says once again that the important thing is to be able to understand your identity in a kanglu way, to let your light shine like light, so that your sufferings becomes your companions; Do you want to be born with your dying ground? Be so close with your relatives that they look for you, if you are eager to do so. Care about the poor, find the survivors. A deeply intelligent, knowledgeable person deeply understands the phenomena surrounding the phenomenon, the spiritual evolution of society and the nation. A person who has the ability to understand increases. Understanding the phenomena of the universe, the ideas of others and the thoughts of others leads to the understanding of the Creator ...As the width moves kanglu also widens, and the kangaroo rises - as if it were raised from the rocks to the mountains. It is up to you to keep yourself above the small things, to become a "slave" of the unworthy things, to live in a world of goodness and to become a citizen of the world of truth, "to become a kanglu, to feel the kanglu". The fact that he does not know what to do is a sign of strangers. Those who despise their own souls are "falling into a rage," and those who do not know their value are "scourged in their interest" and become victims of selfish desires. Thus, a person who does not know his soul wonders around to find it. Because there is a reason why he cannot find his own. There is also a complete description of the symbols of the present-day self-contained in the field of literature, which necessitates the other, with the image of the heart. The negative forces of human nature are commonly called "Lust". Lust cannot trap all human beings. When the tongue is tilted, if the devil is in the body, then the lust:

...сочади ботмонлаб хеч аямасдан:

хийлаю найрангнинг, макру риёнинг,

ёлғону яшшиқнинг, кину хасаднинг,

нифоқу низонинг, қутғу ғавғонинг,

фитнаю иғвонинг, фиску фасоднинг

уруғларини ва кун кўпи билан

секин дил мулкига этмиш хукмрон..

From the symbol of swallow, the poet uses the "kangul" to create a new interpretation. He asked him to light up the stables of the kangul:

Қалдирғоч, канглумга йўл бошла,

Канглум висолга чанқоқ.

Равиш айла, назаринг ташла,

Бардош бекор,

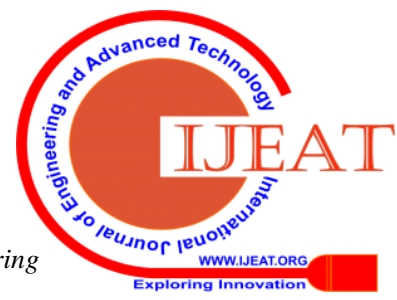


тоқат тоқ!

Kangul's pursuit of his emotions as a kangul, and understanding of the kanglai, is so impressive to I.Otamurod's eyes. The poet describes the extraordinary experiences surrounding the lyric hero - "I" through a poem, or rather, through the symbolic images. In general, the purpose of his approach to the swallow is to draw attention to the state of the heart in a particular environment. Swallows - a symbol of happiness, which reflects the flying aspect of the morning to the daytime, to the point of reaching the kangel. Thanks to the folk oratory, musical compositions can enhance the readability of poetry and facilitate poetic thinking:

Бул қалбимда тоғлар-тоғлар

чўкиб-чўкиб ётар ғам.

Бул қалбимда оғлар-оғлар

тўкиб-тўкиб ётар ғам.

The hearts and minds of the lyrical hero took the form of a song. The poet expresses sufferings in a wide range of a spectacular view. This sadness is the product of the lyric self-expression, "self-indulgence," the sense of self-indulgence, and the increasing sense of self-defeating people.

The Poet's poetic idea is simple, the expression is impressive, but the poem is a solid folklore. Some of them are festive, intoxicant, quick-seated. Ikrom Otamurod, who thoroughly understands the peculiarities of the Uzbek spirit, is trying to convey it to the public and use it efficiently. It enriches our language with words that are present but can not be used slowly, or are forgotten slowly:

\section{... Аввал укданинг ечими - дахрнинг}

муқаддар кечими.

Ёвушади,қовушади кунж,

бир нуқтада занжир тахлит -ғуж.

He uses classical words in his poems to raise his artistic value one more step, which highlights the poet's high respect for our classic literature, classics, classical literature, and perfectly mastered them. The epic of "The Light of Spirit", which has been remembered for the memory of Alisher Navoi, has been so adorned with the clergy of the great scientist that you are in the spirit of that time. Also, in other epics, we observe the classic words as well as it urges us to make a bouquet of classic words and search. This unique phenomenon is remarkable by the enormous role of the reader in the enrichment of the world, the rise of spirituality, and in the development of the ability to understand:

$$
\begin{gathered}
\text {... Хабо - югурдак нўкари тўзоннинг. } \\
\text { Тўзон - хабонинг шаъмунот беги. } \\
\text {... Жадвал - ходислар вуслати ... }
\end{gathered}
$$

In recent epics, there is a phenomenon illustrating the feeling of punctuation by means of punctuation marks (largely a lot of dots) and calling for philosophical contemplation.

The first episode of Ikram Otamurod's "The horses of weak hope" has also become a tradition in his poetry, which he created in recent years. It is not surprising that some of the elements of the lively "I" experience are characterized by the same character as the reader. After all, the pupil comes from the poet's epic and continues to sift through the pseudonym of the poet who does not know the word, and then makes a summary.

\section{..Universe...}

Universe

Table

endless.

The table is limitless,

In epos there are many places where emotions and thoughts are linked only to points without words. In our opinion, these aspects are the deep sorrow of the poet.

In non-traditional poems, the rituals of the traditional poetry system are usually not always followed. This in itself spells some words to write in litle letters. The poet's emotions seemed to be the same as a galloping horse of imagination. The poet does not try to stop the episode of philosophical discourse, he puts it on his own. The stubborn spirit, on the other hand, is in the direction of liberation. In order to draw attention of poem readers towards something, to look more and more deeply, the words may be divided into different parts or sent to them and then sent to our consciousness by writing or reciting the poems by spelling some words or syllables longer:

... Oooonnnneeee tiiimeeeess... . Thee skyyyyyy ...

One of the changes that shapes the poem of the recent epos is these geometric elements. I. This is evident in the creativity of Otamurat. Especially it is characteristic of "The light of the soul".

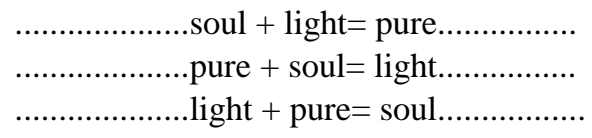

\section{CONCLUSION}

These three concepts always complement each other. It is frightening to imagine one another. Spirit - the world, the world of the soul, the human beings. When a person gives light to his heart, he gets it and becomes pure. A person who is nearer to perfection, and who is a perfect man, is drawn to God. The supreme sign of the perfection is to follow the path of truth and do something beneficial for people. If a person gives a light to the heart of others by his word, his practical deeds, his intentions, and the way he benefits people, he is perfect as long as he is in the way of the Truth.

In the past, in contrast, the peculiarities of the epos of the independence are reflected in the depth of psychological analysis, 
the sophistication of the poetic thinking of the work, the experiences, the feelings of "I" and the changes in shapes. If we write a little bit of research on this subject, our interpretations are just a fraction of the oceans mass.

\section{REFERENCES}

1. Куронов Д. Адабиётшуносликка кириш. - Т.: Фан, 2007. -218 б.

2. Отамурод И. Харитага тушмаган жой. Шеърлар ва достонлар. -Тошкент: Шарқ, 2011. 112 -132 б.

3. Отамурод И. Жадвал. Достон // Шарқ юлдузи, 2016, № 7. 35-45 б.

4. Отамурод И. Куш. Достон// Шарқ юлдузи, 2011, №1. 48-63 б.

5. Мустақиллик даври ўзбек шеьрияти”. Тамойиллар, тажрибалар, сабоқлар. Н. Рахимжонов. Тошкент, ЎзРФА “Фан”, 2007. - 260 б.

6. Жабборов Н. Замон. Мезон. Шеърият. -Т.: Ғафур Ғулом номидаги нашриёт-матбаа ижодий уйи, 2015. - 304 б.

7. Отамурод И. Тағаззул. Шељрлар ва достонлар. -Тошкент: Шарқ, 2008. 124-144 б.

8. Отамурод И. Рухдан сизган нур. Достон// Ёшлик, 2012 йил. № 11-12. 20-23 б. 